constituidos, en orden a posibilitar una tutela axiológicamente valiosa y efectiva de los "vulnerables" de finales de Siglo, esto es los consumidores y usuarios e inclusive subconsumidores y subusuarios - verbigracia, niños, ancianos, destinatarios finales de los productos elaborados, etc. ${ }^{80}$. Y en esta tarea, la reflexión es a la lectura como diez es a uno.

Es que una vez más se verifica que no hay nada más desigual que tratar igual a quienes no son iguales -verbigracia, productores y distribuidores de bienes de consumo o uso masivo como ser franquiciante y franquiciado, en relación a sus destinatarios finales -. Y ello hizo que Couture propusiera en su día que ante la verificación de desigualdades de hecho - verbigracia económicas-, el Derecho debía tender a generar otras desigualdades - de "derecho" - que compensasen a las primeras, lo cual fue receptado en el ámbito - también en su día - del Derecho del Trabajo, y debe serlo ahora en el Derecho del consumidor y del usuario. En palabras de Josserand, la inseguridad material de los contratantes débiles debe recubrirse de seguridad jurídica, debiendo atenderse no sólo al texto normativo, sino también al contexto fáctico, de modo que los avances de la Sociología jurídica se incorporen al entramado de normas y valores y su resultante se incluya como aporte al Derecho vivo, posibilitando todo ello la adecuada solución de los conflictos que genera la conducta en interferencia intersubjetiva.

Por último, y pára concluir este trabajo, se me antoja valioso hacer un breve ejercicio de imaginación, consistente en visualizar a las normas que conforman la Teoría del Daño Resarcible como una suerte de camino empedrado que nos permite introducirnos en un callejón, el que conduce al Derecho del Consumidor y del Usuario; empedrado que a los pocos metros se transforma en pavimento asfáltico y estaría representado por la LDC en su redacción original, lo cual nos presentaba una mejor salida del descripto callejón. Pero a poco que se sigue ilusionadamente avanzando nos topamos con una pared, representada por el art. 6o del Dto. 2089/93 que "observó" - vetó - el referido art. 40 de la LDC. Así los tantos, no debemos desesperanzarnos, dado que situados ante un normativo y aparente callejón sin salida, y recordando que al comienzo del mismo aún contamos con las normas de la Teoría del Responder, debemos tener presente que la salida todavía es posible. Es, hacia atrás, el callejón.
80. Conf. al respecto Ghersi, Carlos A., Modernos conceptos de responsabilidad civil, Ediciones Jurídicas Cuyo, Mendoza, 1995, en especial pp. 212 y 213.

\section{Funções do Estado}

\author{
Maxco Pridalin OPmmex dos Pantos
}

Professor de Instituições de Direito Civil da UFRGS - Advogado ${ }^{1}$

\section{SUMÁRIO \\ I- INTRODUÇÃO.}

II - PERSPECTIVA HISTÓRICA. A) Formação poder e das instituições na Idade Antiga. B) Do primado do feudalismo ao primado do absolutismo. C) Evolução da separação de funções na Inglaterra.

III - FUNÇÕES DO ESTADO E SEPARAÇ̃̃O DE FUNÇÕES. 1. Introdução. A) Funções do Estado 1. Considerações Iniciais 2. Função de Chefia de Estado 3. Função de Chefia de Governo. 4. Função Deliberativa 5. Função Administrativa ou Executiva 6. Função Jurisdicional 7. Considerações finais. B) Separação de Funções 1. Considerações Iniciais. 2. Dinâmica do Sistema Presidencialista. 3. Dinâmica do Sistema Parlamentarista. 4. Considerações finais.

IV - CONCLUSÃO GERAL. $V-B I B L I O G R A F I A$.

\section{I - Introdução}

presente trabalho, adota, sem discutir, princípios emprestados de outras ciências humanas.

Assim, ele se socorre da filosofia adotando o princípio de que o homem nasce livre e dotado de vontade e livre arbítrio, bastando a natureza humana para titulá-lo como igual a seus semelhantes, com os mesmos direitos e deveres.

Aproveita da sociologia o conceito de grupo, que é formado de duas ou mais pessoas que interagem entre si, na busca de uma finalidade. Em todo o grupo, constata-se a realidade inarredável da necessidade de liderança. Ou seja, de que havendo duas ou mais pessoas alguém lidera, decide ou governa, sendo acatado neste exercício pelos demais. Melhor dizendo, todo o grupo, em sua essência, divide-se entre líderes e liderados, coordenadores e coordenados,

1. Trabalho apresentado no curso de mestrado em Direito da UFRGS, na disciplina de Teoria Geral de Direito Público, ministrada pelo professor Almiro do Couto e Silva. 
dirigentes e dirigidos, governantes e governados ${ }^{2}$.

Partindo destes dois princípios, o nosso trabalho examina a sociedade política tendo como fulcro o homem livre dotado de vontade exercendo-a num contexto social, ora na posição de governante, ora na posição de governado. Mas sempre na busca do bem comum, ou seja, daquele bem cujo valor consiste em atender os interesses do todo sem prejuízo do interesse de cada um.

Quando se fala em sociedade, implicitamente se está falando de ordem, orga nização e finalidade, pois o homem não vive ao léo, ao sabor dos seus impulsos tão somente. Ele precisa de trabalho, de organização, de intercâmbio. Estes são objetivos sociais que só podem ser alcançados através de uma linha de pensamento que se transforme numa ação planejada. Eis o objetivo da sociedade politicamente organizada.

O exercício do governo nas socieda des políticas implica, necessariamente, em organização e divisão do trabalho, de forma a permitir uma adequada coordenação entre diversas funções necessárias a consecução de seus fins.

Muitos foram os autores e atores políticos que se debruçaram sobre o tema, embora amplo, mas não esgotado. Neste trabalho, o exame que se faz, das principais obras e instituições políticas, é a homena-

gem que fazemos à aqueles que nos asseguram a liberdade de expressão da qual agora desfrutamos.

O tema central deste trabalho, se constitui do estudo das funções estatais. Para atingir nossos objetivos o dividimos em duas partes. Na primeira, será feita apenas uma narrativa histórica sobre a evolução da atividade funcional do Estado, que servirá de base ao leitor para se chegar a uma segunda parte, mais classificatória, conceitual e analítica do tema.

\section{II - Perspectiva Histórica}

\section{A) Formação do poder e das \\ instituições na Idade Antiga}

O fenômeno do Poder teve como origem primeira de sua criação, a crença do ser humano no divino, no sobrenatural. Esta crença se iniciou já nos povos ascendentes da população greco-romana, de origem indo-européia. Teve como ponto de partida a angústia e o medo do homem pelo término de sua existência com a morte. A religião surgiu da crença acerca da existência da vida sobrenatural após a morte de que quando morria o homem, a sua alma era enterrada com ele. $E$ ali continuava a sua existência, não no céu ou noutro mundo, mas juntamente com o túmulo onde era enterrado.

Apesar de sua existência sobrenatural, a alma conservava seus sentimentos de

2. "O maior de todos os princípios é que ninguém, seja homem, seja mulher, deve carecer de um chefe. Nem deve a mente de qualquer pessoa ser habituada a permitir-he fazer, ainda que a menor coisa, por sua própria iniciativa, nem por zelo, nem mesmo por prazer. Na guerra, como em meio a paz, porém, deve ela dirigir a sua mente para seu chefe e seguí-lo fielmente. E mesmo nas mais ínfimas questōes deve manter-se em submissão a essa chefia. Por exemplo, deve levantar-se, ou mover-se, ou lavarse, ou tomar refeiçōes... apenas se lhe for ordenado que o faça. Numa palavra, deve ensinar sua alma, por hábito prolongado, a nunca sonhar em agir independentemente e a tornar-se totalmente incapaz disto." PLATÃO. prazer e de sofrimento. Por isto, enterravase a pessoa com os objetos que se julgasse viesse a alma a ter necessidade na sua vida futura.

A necessidade de túmulos tornou-se imperiosa, pois a alma que não o tivesse ficava sem morada, sem o descanso a que aspirava após os trabalhos da vida terrena. Era uma alma errante, um fantasma, a atormentar os vivos com doenças e maldições, advertindo de que necessitava de uma sepultura para descansar.

Porém, não bastava uma simples sepultura. Necessário se faziam rituais e oferendas aos mortos, com sacrifícios anu ais; havia o dever oferecer ao morto comida e bebida para satisfazer suas necessidades.

Estes procedimentos foram se consolidando como verdadeiras normas de conduta. Toda a família deveria ter em casa um altar com o fogo sagrado aceso. Cada família tinha o dever de cultuar os seus mortos, para evitar as almas errantes. Os mortos eram, por assim dizer, divinizados a quem os gregos designavam por demônios ou heróis.

Do culto aos antepassados decorreu uma religião doméstica, numa época em que ainda não existiam cidades. Cada família tinha os seus Deuses, que eram constituídos das almas da família. Estas almas precisavam de cultos e e oferendas para que continuassem ao lado de seus túmulos. A regra era a de que só os membros da família podiam cultuar os seus mortos. Às refeições fúnebres, só os membros da família poderiam comparecer com exclusão de todos os demais. Para que o morto recebesse oferendas, deveria obrigatoriamente ter um filho que o sucedesse, do que resultava uma estreita relação entre vivos e mortos. Todos os mortos da família deveriam ser enterrados num mesmo local, próximo ao lar, com exclusão de pessoas de outras famílias.

O pai morto, sempre sendo referendado permanecia próximo ao seu túmulo e próximo a seu filhos, ajudando-os quando necessário, nas horas difíceis. Cada casa, cada família tinha a sua religião, cultuando os seus deuses: os antepassados.

As famílias eram constituídas pelo pai, pela mãe, pelos filhos, pelos clientes e pelos escravos, competindo ao pai a autoridade máxima da família. Esta autoridade advinha da religião, pois o Pai era o sacerdote ou o representante dos deuses no altar. A ele cabia praticar os atos religiosos e os sacrifícios. É ele quem, como representante dos deuses, e em nome deles se pronuncia. O Pai era o chefe supremo da religião doméstica.

Aproximadamente pelo ano de 800 A.C. se consolidaram as cidades, que foram conhecidas por cidades-estado ${ }^{3}$.

As cidades-estado gregas e romanas tiveram como origem famílias desta forma estruturadas. Estas cidades, de início, tinham sua autoridade máxima, tal como nas família, na religião derivada do culto aos seus antepassados. Constituiu-se através da associação religiosa de famílias e de tribos. 
A fundação das cidades era uma cerimônia religiosa na qual primeiramente era fundada a urbe para representar o santuário de culto aos mortos. Os chefes de família quando fundavam a cidade traziam a terra de seu antigo lar, que representava os seus antepassados. O fundador da cidade era o sacerdote de toda a cidade e de sua própria família. Chamava-se por vezes de rei ou de arconde.

Muito embora os deuses da cidade fossem comuns. a todos os cidadãos, cada família conservou os seus cultos e os seus deuses particulares. O chefe da família continuava como autoridade máxima sobre os seus, de forma que o Rei não podia sequer julgar os filhos do chefe da família ou seus escravos.

Estas cidades tinham como vínculo unificador, o culto aos antepassados. Com a união das famílias para a formação das cidades, cada uma delas tinha os seus templos sagrados de culto aos Deuses. Assim como na família, agora, na cidade, somente as famílias que tinham religião podiam participar dos cultos. Isto determinava que aquelas pessoas que não tinham religião, não podiam participar dos cultos.

Aquelas pessoas que tinham religião, eram obrigadas a participar dos cultos. A principal cerimônia do culto da família aos antepassados era o sacrifício, que se constituía de uma refeição. Tal como na família, antiga, também em relação aos Deuses da cidade dever-se-iam praticar sacrifícios, que eram banquetes onde somente os cidadãos poderiam participar dos cultos. Neles, os

\section{DE COULANGES, Fustel, A cidade antiga, pág 15}

sacerdotes de cada família participavam na condição de cidadãos.

Nas cidades formadas pela religião só tinham direitos as famílias religiosas. Só eram cidadãos aqueles que pertenciam à famílias. Em cada família o seu chefe ou sacerdote exercia o direito de cidadania em nome dos demais, ou seja, a esposa, os irmãos mais novos do chefe de família, os filhos do chefe da família e os clientes exerciam seu direito de cidadania só através do chefe de família. Este, por sua vez, dentro da família, era o juiz, o chefe religioso. O Rei nunca poderia julgar um membro de família que não a sua própria. Só poderia mesmo julgar o chefe da família.

As cidades eram governadas por uma forma de Estado monárquica, constituídas pela união das famílias que inicialmente a formaram.

Os reis eram sacerdotes ou chefes de famílias. Sua autoridade estava para a cidade assim como a do chefe de família para sua família. Sua autoridade derivava das regras do culto aos antepassados. A hereditariedade manifesta-se como regra para transmissão do culto. Fosse o lar de alguma família, fosse o lar de alguma cidade, a religião prescrevia que o cuidado de sua conservação passasse de pai para filho.

O sacerdócio foi, portanto, hereditário, assim como o próprio poder ${ }^{4}$.

Nestas cidades a autoridade derivava do culto ao lar, como decorrência do culto doméstico aos antepassados. Assim como na família, a cidade mantinha um só sacerdote ou chefe (Rei): Aristóteles designava este governo como sendo uma Monarquia ${ }^{5}$.

O primeiro conflito no poder destas cidades deu-se entre a aristocracia e a monarquia. A aristocracia era composta dos chefes de família. Estes tinham no seio de suas famílias o mesmo poder régio do Monarca em relação à cidade. Unidos, os chefes de família tinham mais poder do que o Rei sozinho. Este tinha de ser político hábil para manter apoio dos chefes de família e, ipso facto, para manter-se no poder.

Em toda a Grécia, não demorou muito para que a aristocracia prevalecesse sobre o poder dos reis. A aristocracia visava suprimir a realeza política mantendo a realeza religiosa. Fundava-se ainda na religião, pois os chefes de família eram sacerdotes. Como decorrência disto, as regras de hereditariedade de culto do lar, de privilégio do primogênito, e, conseqüentemente, do direito de pronunciar as orações ligado ao nascimento, permaneciam.

Só os sacerdotes podem ser cidadãos só os cidadãos podem ser magistrados: aqueles que exercem o Poder ou alguma função pública.

Esta forma de sociedade somente se altera na medida em que a estrutura familiar se altera por decorrência da extinção do privilégio da primogenitura, base da unidade da familiar. Este fenômeno teve inúmeras conseqüências, dentre elas, a

5. ARISTÓTELES, A Politica, p. 177.

6. DE COULANGES, Fustel, A cidade antiga, pág 17

7. CROISET, A., As Democracias Antigas, pág. 20.

8. DE COULANGES, Fustel, $A$ cidade antiga, pág. 22. extensão do título de cidadão aos irmãos mais novos e a divisibilidade da propriedade dentre os filhos. Apenas o privilégio do sacerdócio hereditário foi conservado por mais tempo, com funções unicamente religiosas $^{6}$.

As cidades dividiam-se ainda em duas classes de pessoas: os cidadãos e a plebe. A base desta distinção era a religião. Somente podiam cometer sacrifícios aqueles que tivessem uma religião; somente pessoas que tivessem uma religião podiam ser cidadãos. Logo, a plebe não tinha o direito de cidadania.

Esta inferioridade foi suprimida pela lei de Sólon que instaurou a igualdade civil entre as duas classes. O código de Sólon permite o surgimento da democracia gre$\mathrm{ga}^{7}$.

O princípio do interesse público (res publica) passou a governar as cidades, em substituição ao interesse anterior de unificação da sociedade: a religião. $\mathrm{O}$ sufrágio passou a exercer a soberania ${ }^{8}$.

Em Atenas, havia magistrados que não eram sacerdotes e que exerciam as mais diversas funções. Havia dez estrategistas que se ocupavam com os negócios da guerra e da política; dez astínomos que cuidavam da polícia; quinze metrônomos que cuidavam dos pesos e medidas; dez recebedores de impostos, etc. Estas magistraturas eram anuais e muitas vezes os cidadãos eram escolhidos para as exercer, conforme a ci- 
dade, por sorteio ou mesmo por rodízio. $\mathrm{O}$ Senado era composto por sacerdotes e deliberava acerca de interesses religiosos e políticos da cidade.

Acima das magistraturas e do próprio Senado estava a assembléia do povo propriamente dita. Este aprovava ou rejeitava as leis propostas pelo Senado. O povo reunido na ágora, em assembléia não tinha o poder de iniciativa de leis. O poder de deliberação cabia ao Senado. Este foi o auge da democracia grega ${ }^{9}$.

As cidades romanas formaram-se de forma semelhante as gregas, baseadas na religião doméstica. As suas transformações internas também o foram semelhantes.

Em Roma, houve uma fase monárquica sendo o poder político exercido por um rei eleito pelo Senado. O Senado era composto pelos chefes de famílias. Reúne tanto o poder religioso como o político em suas mãos. Nesta condição o Rei comandava o exército, cometia os sacrifícios, julgava as questões civis e criminais e convocava o Senado juntamente com o povo $^{10}$.

O Senado possuía grande autoridade pois elegia os reis. Todas as questões levadas ao povo pelo Rei eram antes discutidas no Senado ${ }^{11}$.

O povo elegia os magistrados, exercia o poder de veto de novas leis; aprovava

9. GILISSEN, John, Introdução Histórica ao Direito, pág. 81.

10. MONTESQUIEU, Do Espírito das Leis, pág. 165.

11. MONTESQUIEU, Do Espirito das Leis, pág. 165.

12. MONTESQUIEU, Do Espirito das Leis, pág. 165.

13. BURNS, Edward Mcnall, História da Civilização Ocidental, pág. 235.

Revista da Faculdade de Direito da UFRGS, v. 13, 1997 novas guerras e celebrava a paz quando o Rei o permitia ${ }^{12}$.

A Monarquia romana, tal como a Grega converteu-se em República, resultado do confronto entre a aristocracia, representada pelo Senado, e o Rei.

Os objetivos do Estado se alteraram: na monarquia a autoridade baseava-se no culto aos. deuses tendo como objetivo assegurar os sacrifícios e os ritos religiosos; na república o interesse passou a ser o bem comum.

Dos sacrifícios religiosos passaram a participar também os plebeus, que neles viam meras formalidades.

A República passa a ser governada pelo Senado que aumentou o seu poder controlando os fundos públicos; substituiu o Rei por dois cônsules. Estes, eram normalmente Senadores e governavam conjuntamente, mas cada um deles tinha a autoridade executiva e judicial da qual dispunha anteriormente o Rei. Em caso de conflito entre ambos o Senado dirimia podendo inclusive nomear um ditador pelo prazo máximo de seis meses ${ }^{13}$.

A sociedade Romana formou-se da união de três tribos: tribos dos albanos, sabinos e etruscos-úmbrios.

Cada uma destas tribos era dividida por cúrias. Cada uma das tribos foi dividida igualitariamente por dez cúrias, somando um total de 30 cúrias, das quais cada uma possuía seus templos, seus deuses, sacerdotes e sacrifícios ${ }^{14}$.

Com o advento da república, Sérvio mudou a divisão das classes romanas, abolindo as raças e substituindo-as por outra divisão baseada nos lugares da cidade ocupados pelas tribos. Ao invés das três tribos, organizou a sociedade romana em quatro: cada uma ocupava uma colina de Roma ${ }^{15}$. Impediu que os habitantes passassem de uma tribo para outra. Além destas quatro tribos, foram incorporadas umas tantas outras provenientes dos chamados povos rústicos, que eram formadas pela população rural somando um total de trinta e cinco tribos $^{16}$.

Com a nova divisão feita por Sérvio, o total de 30 cúrias não pode ser dividido igualitariamente entre as quatro tribos da cidade $^{17}$. Em razão disto, Sérvio manteve a divisão anterior por cúrias.

Foi feita ainda uma terceira divisão, sem se basear nas anteriores, cujo critério predominante era a riqueza. Como destaca Rousseau, pelos seus resultados, esta foi a mais importante de todas ${ }^{18}$

Distribuiu o povo entre seis classes, sendo as primeiras ocupadas pelos ricos, as

14. ROUSSEAU, Jean-Jacques, Do Contrato Social, pág. 132 15. ROUSSEAU, Jean-Jacques, Do Contrato Social, pág. 131. 16. ROUSSEAU, Jean-Jacques, Do Contrato Social, pág. 132.

17. ROUSSEAU, Jean-Jacques, Do Contrato Social, pág. 132.

18. ROUSSEAU, Jean-Jacques, Do Contrato Social, páa. 133

19. ROUSSEAU, Jean-Jacques, Do Contrato Social, pág. 133.

20. GILISSEN, John, Introdução Histórica ao Direito, pág. 82. e ROUSSEAU, Jean-Jacques, Do Contrato Social, pág. 133.

21. ROUSSEAU, Jean-Jacques, Do Contrato Social, pág. 133

22. GILISSEN, John, Introdução Histórica ao Direito, pág. 82. últimas pela pobreza (a proletarii) e as médias por aqueles que gozavam de fortuna medíocre $^{19}$.

Estas seis classes foram divididas em cento e noventa e três centúrias, das quais a classe rica predominava em oitenta ${ }^{20}$.

Cada tribo, cada cúria e cada centúria possuía um voto nos comícios e estes se realizavam ou por tribo, ou por cúria ou por centúrias. Durante a república os comícios por centúrias predominavam. O resultado foi que a classe menos numerosa em homens era a mais numerosa em centúrias, e que a última só representava uma subdivisão, ainda que compreendesse sozinha mais da metade dos habitantes de Roma ${ }^{21}$.

A esta última classe, a fim de que o povo percebesse menos as conseqüências desta divisão, Sérvio deu-lhe feição militar.

As prerrogativas da centuriata comitia era a de eleger os cônsules, os pretores e votar as leis. Todavia, os candidatos às magistraturas eram propostos pelos seus predecessores, cabendo aos centuriata comitia o poder de confirmarem ou recusarem o candidato ${ }^{22}$.

O poder legislativo desta forma era exercido pelo povo, cabendo ao Senado e

Revista da Faculdade de Direito da UFRGS, v. 13, 1997 
aos cônsules a função executiva. $O$ senado dispunha do dinheiro público, era o árbitro do negócio dos aliados, decidia a guerra e a paz orientando os cônsules. Os cônsules procediam ao levantamento da tropa, comandavam o exército faziam a paz com os povos vencidos, impunham-lhes as condições ou enviavam-nas ao senado ${ }^{23}$.

O poder de julgar primeiramente era dos reis, posteriormente passou aos cônsules e depois aos pretores. A lei Valeriana proibiu aos cônsules de aplicar a pena capital permitindo ao réu apelar ao povo que era composto de patrícios, senadores e plebeus $^{24}$.

A passagem da República ao Império faz-se lentamente. O progresso econômico, as dificuldades sociais, as vastas conquistas durante o século I a.c. provocaram uma crise política que tentativas de reformas buscaram remediar sem êxito. Octávio conseguiu centralizar em suas mãos todos os poderes deixando subsistir as instituições da República. Recebeu do Senado o título de Augusto, o imperium proconsular. Foi proclamado imperator desvinculado da lei $^{25}$.

Daí por diante o regime político tornou-se o do Império, no qual todos os poderes ficaram concentrados nas mãos do imperador ${ }^{26}$.

O Imperador Constantino em 313 d.c. reconheceu a religião cristã e fundou a

\section{MONTESQUIEU, Do Espirito das Leis, pág. 169}

24. MONTESQUIEU, Do Espirito das Leis, pág. 171.

25. GILISSEN, John, Introdução Histórica ao Direito, pág. 83.

26. MOSCA, Gaetano, História das Doutrinas Políticas, completada por Gaston Bouthoul, pág. 63; GILISSEN, John, Introduçăo Histórica ao Direito, pág. 84: nova capital de Constantinopla dividindo o Império Romano em dois: o do ocidente que afundou no século $V$ e o do oriente que sobreviveu até o século XV.

\section{B) Do primado do feudalismo ao} primado do absolutismo

A queda de Roma, sob a espada Odocero, em 476 D.C. assinala o fim da Idade Antiga. Inicia-se a Idade Média. O cristianismo desde o seu reconhecimento como igreja oficial do Império Romano, sob o cetro de Constantino, passa a ter forte influência sobre os indivíduos. Os antigos templos da religião romana de culto aos antepassados tornam-se igrejas. Diferentemente das antigas religiões, a cristã é revolucionária, pois o seu Deus é universal.

- Seus princípios também o são, tais como, "amarás o teu Deus sobre todas as coisas", "amarás o próximo como a ti mes mo", "ama teus inimigos" faz o bem a quem te odeia", entre outros.

O esfacelamento do Império Romano, a partir das invasões bárbaras assinala o retorno das cidades-estado as quais se designou por feudos.

As instituições políticas feudovassálicas da idade média, que deram origem as constituições da idade moderna, só tiveram início a partir do império carolíngeo, no ano de 800 d.c., quando o papa coroou Carlos Magno Imperador.
Os governos eram exercidos pelos senhores feudais. Bastava ser possuidor de um feudo para governar.

Estes governos baseavam-se num contrato entre suseranos e vassalos e, como tal, teoricamente qualquer das partes po deria denuncia-lo ${ }^{27}$. O limite do poder dos senhores feudais residia no poder de con tenção da autoridade eclesiástica, que representava o poder espiritual na terra

Assim, os governantes se comprome tiam a governar com justiça, de acordo com as leis divinas e laicas. O súdito, enquanto o senhor não violar o contrato, fica obriga do a obedecer ao seu senhor.

Deste respeito ao contrato entre vassalo e suserano, deduz-se que o governo nos feudos era limitado, em oposição à au toridade absoluta ${ }^{28}$

É bem verdade que estas instituições muito se diferenciam das instituições polí ticas modernas. Todavia, não se lhes pode negar que tinham como objetivos manter a paz interior e exterior. Os governos feudai administravam a justiça, regulavam os as suntos sociais, pesos e medidas, cunhavam moedas. Em razão disto, também proporci onavam meios materiais para atingir estes objetivos, tais como, a construção de edifí cios públicos e o pagamento de funcionários e soldados ${ }^{29}$

As constituições da europa medieval em geral eram monárquicas. Apesar de o Rei não continuar sendo um sacerdote, como nas monarquias gregas e romanas, continua sendo o governante da cidade, com as atribuições de juiz e de general, assim como o chefe da família o era nas épocas primitivas.

O cargo da realeza também era hereditário, muito embora o princípio da primogenitura não fosse critério prevalente para a sucessão do trono.

O Rei tanto podia dividir o feudo dentre os seus filhos, como podia deixá-lo sob a administração de um tio ou a um irmão. Somente mais tarde adveio o princípio da indivisibilidade, juntamente com o conceito de nacionalidade.

As decisões do reino eram tomadas com a aprovação dos conselhos, formados por vassalos de feudos menores sob o seu comando. Todavia, a atividade administrativa limitava-se a promulgação do que hoje poder-se-ia se denominar de decretos administrativos. O governo feudal era um governo de leis, não de homens. A lei civil era um produto dos costumes ou da vontade divina a que o Rei e mesmo os vassalos ou senhores feudais tinham de respeitar ${ }^{30}$.

O sistema mantinha um equilíbrio eficaz entre o absolutismo e a anarquia, mediante a, evolução gradual de um governo representativo. Apesar de os conselhos de senhores feudais e de bispos não serem eletivos, não perdiam, só por este fato, o

27. CRUMP, C. G., e JACOB, E. F., El legado de la Edad Média, pág. 606, e BURNS, Edward Mcnall, História da Civilizaçâo Ocidental, pág. 334.

28. BURNS, Edward Mcnall, História da Civilização Ocidental, pág. 334

29. CRUMP, C. G., e JACOB, E. F., El legado de la Edad Média, pág. 598.

30. BURNS, Edward Mcnall, História da Civilização Ocidental, pág. 334. 
seu caráter de órgão representativo e limitador da autoridade real ${ }^{31}$.

Os Conselhos de Bispos e de Senhores estavam capacitados para aconselhar o Rei acerca de determinada decisão, alertando-o se esta era ou não conveniente para sua segurança no trono.

Estes princípios não eram específicos e definidos, mas no geral sobre os assuntos importantes o rei deliberava assessorado por estes conselhos.

A função judiciária, como já relatado, era exercida pelos senhores feudais, nos respectivos territórios. Havia uma disputa entre os vassalos e os suseranos acerca da competência para julgar. Na medida em que o poder real enfraquecia, prevalecia a jurisdição local. O Rei, no entanto, procurava assegurar o direito de julgar a nível de apelação. Quando o poder real aumentava, além de julgar a nível de apelação, este controlava também a jurisdição local através da extensão de sua jurisdição às localidades. Para tanto, nomeava pessoas de sua confiança para dizer o direito. Havia um direito real de inspeção das jurisdições locais.

Ao julgar as lides a nível de recurso, o rei reforçava o seu apoio popular nas bases, enfraquecendo os senhores locais. Este jogo de forças entre aristocracia e realeza já ocorria mesmo nas monarquias gregas, onde os reis aliavam-se aos pobres para libertarse do jugo do Senado ${ }^{32}$.

31. CRUMP, C. G. e JACOB, E. F., El legado de la Edad Média, pág. 614

32. DE COULANGES, Fustel, A cidade antiga, pág. 352

33. BURNS, Edward Mcnall, História da Civilizaçăo Ocidental, pág. 425.

34. HOBBES, Thomas, LEVIATÃ ou matéria, forma e poder de um Estado Eclesiástico e Civil, pág. 114

No final da idade média, alguns fatos relevantes concorreram para desequilibrar este jogo de forças entre a nobreza e o Rei. A guerra das rosas entre facções rivais de barões, na Inglaterra, enfraqueceu a nobreza e tornou propícia a concentração do poder sob o comando da dinastia dos Tudors, em $1455^{33}$. As cruzadas também foram fator determinante do enfraquecimento dos feudos, do que redundou uma gradativa preponderância do poder monárquico sobre o poder feudal. Disto resultou a formação dos estados nacionais, primeiramente na França, Inglaterra e Espanha.

Portugal, condado portugalense, onde Senhor feudal, Duque de Borgonha tornou-se Rei, sem intermediários entre o povo e o poder real, é apontado por muitos historiadores, como o primeiro estado nacional moderno.

Os poderes estatais concentram-se nas mãos do Rei, com poderes absolutos e ilimitáveis: "Dado que o direito de representar a pessoa de todos é conferido ao que é tornado soberano mediante um pacto celebrado apenas entre um e cada um, e não entre o soberano e cada um dos outros, não pode haver quebra do pacto por parte do soberano e, portanto, nenhum dos súditos pode libertar-se da sujeição, sob qualquer pretexto de infração por parte do soberano", afirmava Hobbes ${ }^{34}$

A idéia de que o soberano não pode ser punido pelos atos injustos que pratica,

Revista da Faculdade de Direito da UFRGS, v. 13, 1997 mesmo que cometidos contra os súditos, caracterizava a ilimitação de poder.

Concentram-se na pessoa do sobe rano, a autoridade judicial, legislativa e executiva.

A queda de Constantinopla em 1553 assinala o fim do Império Romano do oriente. Do oriente emigram sábios e artistas para o ocidente. Esta onda cultural que se espraia na Europa deu origem à renascença.

O direito privado começa a sofrer novas influências decorrentes do renascimento da cultura greco-romana. Há uma tendência para a sua unificação do direito dentro das novas nações e dos grandes principados, tendo como fonte do direito, cada vez mais o soberano em nome do Estado. Isto gera o absolutismo.

C) Evolução da separação de pode res na Inglaterra

O absolutismo criara um espírito nacionalista do que resultou um direcionamento para o exercício do poder a nível nacional, em detrimento do poder feudal ou local.

Foi na Inglaterra que o poder absoluto do Rei, pelos anos de 1.200 D.C., começou a ser primeiramente contestado. $\mathrm{O}$ jogo de forças entre a nobreza e a monarquia ainda subsiste, apesar do predomínio do poder real sobre a nobreza.
O Parlamento, herdado da idade média, era composto da câmara dos comuns e da câmara dos lordes. Houve na Inglaterra uma fusão entre parte da nobreza menos influente e o terceiro estado, redundando na formação da câmara dos comuns. A câmara dos lordes era formada pelos grandes senhores feudais ${ }^{35}$.

Os Senhores Feudais freqüentemente eram convocados pelo Rei a se reunirem no Parlamento para discutir sobre as finanças necessárias para financiar as guerras

A dinastia dos Tudors mantém a preponderância do poder real de 1485, final da guerra das duas rosas, até o ano de $1603^{36}$. Durante este período, muito embora o Rei convocasse o parlamento com frequência, continuava ele exercendo o seu poder de forma absoluta, tanto quanto o Rei da França ${ }^{37}$. O Rei exercia sua jurisdição local nomeando magistrados de sua confiança, que normalmente eram pessoas de renome nas localidades.

Havia uma relação de interdependência entre o Rei e parlamento. Este com, representatividade local, procurava impor-se ao Rei através da edição dos Bill of Rigths. Cada vez que o Rei convocava o parlamento para levantar recursos financeiros, o parlamento lhe impunha um Bill.

O Rei Carlos I, quando assumiu o trono resolveu declarar guerra à França com

35. CRUMP, C. G., e JACOB, E. F., El legado de la Edad Média, pág. 614.

36. MOSCA, Gaetano, História das Doutrinas Políticas, completada por Gaston Bouthoul, pág. 161

37. MOSCA, Gaetano, História das Doutrinas Políticas, completada por Gaston Bouthoul, pág. 161. 
o intuito de socorrer os huguenotes de La Rochelle, que também eram protestantes e lhe haviam pedido ajuda.

O Rei Carlos I convocou o parlamento que lhe forneceu subsídios necessários para socorrer a cidade sitiada. Sucedeu que os ingleses perderam a batalha e tiveram de retornar ${ }^{38}$.

O Rei e os nobres acusaram-se mutuamente acerca das responsabilidades pelo fracasso. O Rei dissolveu por duas vezes o parlamento convocando a outros na busca de ajuda financeira. Um terceiro Parlamento foi convocado e concordou em fornecer mais subsídios mediante a aprovação do chamado Bill of Rights (ato de direitos) que impunha restrições ao exercício do poder régio.

Aproximadamente em 1625 ocorreu o $1^{\mathrm{o}}$ Bill of Rights no qual ficou definido que $^{39}$ :

1. O Rei não poderia cobrar impostos, sequer sob a forma de contribuições ou doações sem consentimento do parlamento;

2- ninguém poderia ser perseguido por se recusar a pagar impostos não autorizados pelo parlamento.

O Rei Carlos I não cumpriu as determinações deste Bill of Rights. Houve uma guerra civil entre os parlamentares, de um lado, e o Rei Carlos I, de outro.

38. MOSCA, Gaetano, História das Doutrinas Políticas, completada por Gaston Bouthoul, pág. 168.

39. MOSCA, Gaetano, História das Doutrinas Políticas, completada por Gaston Bouthoul, pág. 168.

40. MOSCA, Gaetano, História das Doutrinas Políticas, completada por Gaston Bouthoul, pág. 173.

41. MOSCA, Gaetano, História das Doutrinas Políticas, completada por Gaston Bouthoul, pág. 176. da mulher, este foi batizado católico. $\mathrm{O}$ direito deste príncipe excluía da sucessão as filhas protestantes do Rei. O parlamento sentiu o temor de instalar-se novamente na Inglaterra uma dinastia de religião católica, com tendências absolutistas ${ }^{42}$.

O Parlamento procurando evitar este perigo firmou um acordo com o príncipe Guilherme de Orange, que era casado com a filha mais velha de Jaime II, para a deposição do rei.

Em 1688 Guilherme de Orange in vade a Inglaterra com seu exército, recebendo o apoio do parlamento Inglês. Diante da impopularidade do Rei Jaime II, não houve maiores dificuldades para derrubálo. O Rei Jaime II refugiou-se na França jogando o sinete real no Tâmisa ${ }^{43}$. Guilherme Orange e Maria, sua esposa, foram proclamados respectivamente Rei e Rainha da Inglaterra. Efetivou-se, desta forma, o que os ingleses chamaram de revolução gloriosa.

Em 1689 o Parlamento discutiu e aprovou o segundo Bill of Rights determinando que ${ }^{44}$ :

1- Os reis da Inglaterra deveriam ser protestantes;

2- Nenhuma guerra podia ser declarada sem o consentimento do parlamento;

3- Nenhum estrangeiro poderia fazer parte do Conselho Privado
4- Todas as decisões reais para terem força executória, deveriam ser contra-assinadas por um membro do Conselho Privado;

5- Todas as decisões reais, para ter força executória, deveriam ser aprovadas por um membro do Conselho Privado;

6- Todos os juízes deveriam ser nomeados em função de sua conduta exemplar;

7- O rei não podia suspender o processo de impeachment;

8- Nenhum soberano inglês poderia deixar a Inglaterra sem 0 consentimento do Parlamento.

A partir daí, o parlamento assume definitivamente a condição de legislador independente do poder régio. Como bem acentua Gaetano Mosca ainda, não se poderia denominar o regime inglês como sendo o parlamentar.

O Conselho Privado, a que se fez alusão no Bill of Right de 1689 , era um corpo político que assistia o soberano no exercício de suas funções políticas, composto de 50 a 60 membros aproximadamente. O número de membros era excessivo, tornandoo pouco apto para exercer as suas funções rapidamente e em segredo, quando necessário.

No reinado de Carlos II, afim de evitar estes inconvenientes, reduziu-se esse

42. MOSCA, Gaetano, História das Doutrinas Políticas, completada por Gaston Bouthoul, pág. 177.

43. MOSCA, Gaetano, História das Doutrinas Políticas, completada por Gaston Bouthoul, pág. 177.

44. MOSCA, Gaetano, História das Doutrinas Políticas, completada por Gaston Bouthoul, pág. 179. 
número aos quatro ou cinco membros mais influentes do Conselho Privado. Estes discutiam os assuntos mais importantes, e posteriormente os levavam à reunião plenária do Conselho. Este grupo restrito do Conselho, que também atuou nos reinados de Jaime II, de Guilherme II e da rainha Ana, foi denominado Gabinete.

Em 1714, o primeiro Rei da Dinastia de Hanover, Jorge I, que só falava o idioma alemão, teve a idéia de chamar para o $\mathrm{Ga}$ binete os membros mais influentes da Câmara dos Comuns. Por influência de Horácio Walpole, conselheiro do Rei durante quase vinte anos, Jorge I passou a es colher para a composição do Gabinete somente membros do partido majoritário, que na época eram os Whigs. Como Jorge I sequer entendia a língua inglesa, o Gabinete passou a reunir-se sem ele, adquirindo o hábito de simplesmente submeter à sua assinatura as decisões tomadas sem a sua presença. Foi desta forma que o Gabinete, órgão até então desconhecido pela constituição inglesa, passou a exercer de fato o poder executivo ${ }^{45}$.

Jorge II, filho do Rei, seguiu o exem plo do pai abstendo-se completamente. Seu sucessor, Jorge III, nascido na Inglaterra, foi o último rei que procurou ainda conservar as prerrogativas da antiga monarquia. Após o seu reinado tornou-se impossível, na Inglaterra, governar sem o apoio de um dos partidos políticos ${ }^{46}$.
Foi a partir desta época que um governo parlamentar puro estabeleceu-se na Inglaterra $^{47}$.

As grandes modificações ocorridas posteriormente no parlamento, foram decorrentes do sistema eleitoral dos seus integrantes. Havia três correntes doutrinárias divergentes. $O$ partido conservador pregava que apenas os proprietários de terras deveriam exercer o direito de voto.

Uma segunda corrente defendia que se deveriam enquadrar como eleitores também os proprietários de bens móveis, que eram os grandes industriais da época ${ }^{48}$. Por certo não havia a idéia de bem imóvel por acessão física. Havia também uma corrente democrática, influenciada pelos franceses, que defendia o sufrágio universal.

A segunda corrente acabou prevalecendo. Somente no ano de 1867 o direito de voto foi estendido a todos os chefes de família. Após a segunda guerra mundial (1939/1945) o sufrágio foi concedido às mulheres.

\section{II - Funções Estatais e Separação De Funções}

\section{Introdução}

O presente capítulo está dividido em duas partes:

Na primeira parte (A) estudaremos o conceito de função estatal, partindo de

\section{MOSCA, Gaetano, História das Doutrinas Políticas, completada por Gaston Bouthoul, pág. 182. \\ 46. Jorge III morreu em 1810.}

47. MOSCA, Gaetano, História das Doutrinas Politicas, completada por Gaston Bouthoul, pág. 182.

48. Nota do autor: Benjamim Constant dedica um capítulo de sua obra Princípio Políticos Constitucionais para fundamentar a idéia da propriedade imobiliária como condiçăo para o exercício dos direito de voto. Isto porque, segundo ele, "somente a propriedade assegura o ócio necessário à capacitação do homem para o exercício dos direitos políticos".

Revista da Faculdade de Direito da UFRGS, v. 13, 1997

uma visão geral e introdutória, para chegar, posteriormente, à sua especificidade, traçando-lhe também os seus objetivos.

$\mathrm{Na}$ segunda parte (B) deste capítulo analisaremos o instituto da separação de poderes, seus objetivos e formas de funcionamento nos sistemas presidencialista e parlamentarista de governo.

\section{A) Funções do Estado}

\section{Considerações iniciais sobre o tema}

O Estado, na doutrina predominante, é constituído por território, povo e so berania. O Estado na comunidade internacional é visto como uma personalidade jurídica. Esta pessoa, como resultado da soma de pessoas políticas individuais, deve organizar-se internamente. Nas democracias a soberania, concebida como o poder que a comunidade detém de auto-governar-se frente as demais, é exercida pelo povo, através de um governo.

Chama-se Estado de Direito aquele que se organiza apoiado em leis, das quais a mais importante e da qual se originam as demais é a Constituição, onde se estabelecem os objetivos da sociedade e os meios pelos quais se pretende atingi-los.

Estado deve organizar-se e autoreger-se politicamente para atingir seus objetivos. $\mathrm{Na}$ impossibilidade de todas pessoas se auto-governarem, pois que a vontade de

49. HOBBES, Thomas, LEVIATÃ ou matéria, forma e poder de um Estado Eclesiástico e Civil, pág. 54 50. ARISTÓTELES, A Política, livro VI, capítulos XI, XII e XIII, págs. 202, 205 e 210 respectivamente. 51. MONTESQUIEU, Do Espirito das Leis, pág. 156. cada um dos indivíduos diverge da vontade coletiva, a sociedade delega o exercício do poder político a uma pessoa ou a um grupo de pessoas saídas dela mesmo ${ }^{49}$. Desta delegação de poder deriva uma divisão social e uma relação de mando-subordinação entre uns e outros; entre governantes e governados. Aos governantes cabe a missão de exercício do poder político em nome dos demais. Nesta condição, exerce funções estatais.

Pode-se, pois, dizer que as funções do Estado são a forma pela qual os governantes exercem o seu poder no âmbito de uma dada sociedade.

As três funções clássicas de deliberação, execução e jurisdição, são originárias da doutrina política de Aristóteles ${ }^{50}$.

Em 1748, Montesquieu publica sua obra histórica onde se referiu as três funções da seguinte forma"1: "Há em cada Estado, três espécies de poderes: o poder legislativo, o poder executivo das coisas que dependem das gentes, e o poder executivo das coisas que dependem do direito civil. Pelo primeiro, o príncipe ou magistrado faz leis por certo tempo ou para sempre e corrige ou $a b$ roga as que estão feitas. Pelo segundo, faz a guerra, envia ou recebe embaixadas, estabelece a segurança, previne as invasões. Pelo terceiro, pune os crimes ou julga as querelas dos indivíduos. Chamaremos a este último o poder 
de julgar e, ao outro, simplesmente o poder executivo do Estado."

A estas três devem ser acrescidas mais duas funções estatais: a Chefia de Estado, concebida pelo francês Benjamim Constant sob inspiração da Constituição Inglesa, também denominada de Poder Moderador 51; a função executiva ou administrativa, que caracterizou os Estados intervencionistas deste século $\mathrm{XX}^{52}$.

Portanto, ao contrário do que poderíamos imaginar prima facie, por vivermos num sistema presidencialista, mesmo no âmbito dos tradicionais poderes Legislativo, Executivo e Judiciário, são exercidas cinco funções estatais: de Chefia de Estado, de Chefia de Governo, Deliberativa, Executiva e Jurisdicional.

Com o objetivo de expor as principais características de cada uma destas funções estatais, passamos a realizar uma análise suscinta de cada uma delas, nesta mesma ordem.

\section{Função de Chefia de Estado}

A Chefia de Estado surgiu como decorrência natural da evolução constitucional inglesa. Como vimos, Rei Jorge I, da dinastia de Hanover, era alemão e desconhecia a língua inglesa. Em razão da dificuldade de se comunicar com o parlamento, passou a convocar um pequeno grupo de nobres da Câmara dos Comuns para se reunir em seu gabinete. Tempos depois, o gabinete passou a ser composto apenas de membros do partido majoritário. E como o Rei pouco se interessava pelos assuntos políticos partidários, o gabinete passou a deliberar e decidir sozinho, pois a assinatura do Rei tornou-se mera formalidade.

Em sua obra clássica, Benjamim Constant, afirmava que o grande vício das constituições até então vigentes, era o de não terem criado um poder neutro e acima dos demais, o qual, nesta condição poderia evitar que um dos poderes destruísse outro $^{53}$.

$\mathrm{Na}$ Inglaterra, no entanto, tal distinção já era uma realidadé. Benjamim Constant, ao sustentar esta distinção indicava a Inglaterra como exemplo. "Para fixar melhor minhas idéias ..." declara Benjamim Constant "... rogo ao leitor que coteje minhas afirmações com a realidade ..." 54 . "Esta realidade ..." prossegue Benjamim Constant, "... encontra-se na monarquia inglesa que criou este poder neutro e moderador, o poder real, independente do executivo ${ }^{55 " .}$

52. N. do autor: "Temos aqui a palavra poder empregada em dois sentidos diversos: - Quando utilizamos a palavra poder e que implícita ou explicitamente a adjetivamos com a palavra político, nos referimos a uma relação de mando-subordinaçăo entre estado e cidadão.

- Quando utilizamos a palavra poder adjetivando-a com uma função estatal (legislativa, executiva, etc..) a identificamos como sinônimo de órgão que exerce funçōes estatais.

53. REBECQUE, Henri Benjamin Constant de, Princípios Políticos Constitucionais: princípios políticos aplicáveis a todos os governos representativos e particularmente à Constituição atual da França (1814).

54. REBECQUE, Henri Benjamin Constant de, Princípios Políticos Constitucionais: princípios políticos aplicáveis a todos os governos representativos e particularmente à Constituição atual da França (1814), pág. 74.

55. REBECQUE, Henri Benjamin Constant de, Princípios Políticos Constitucionais: princípios políticos aplicáveis a todos os governos representativos e particularmente à Constituição atual da França (1814), pág. 74. N. do Autor: A palavra executivo a que se refere Benjamim Constant, é o que, em linguagem moderna se entende por Chefia de Governo.

Revista da Faculdade de Direito da UFRGS, v. 13, 1997

A partir desta obra clássica, passouse a fazer a distinção entre a Chefia de Estado e a Chefia de Governo: o rei como Chefe de Estado e o Primeiro Ministro, como Chefe do Governo formado pelo $\mathrm{Ga}$ binete.

A este fenômeno político, a doutrina atribuiu, na Inglaterra, a denominação de Monarquia Constitucional. Não se tratava mais da Monarquia dos Estados absolutistas, mas de uma Monarquia limitada, à semelhança das Monarquias medievais ${ }^{56}$.

Ao examinar a Constituição francesa de 1814, Constant procura demonstrar a existência desta separação entre o poder do ministério e o poder real. Concluiư que "... na medida em que a Constituição estabelece responsabilidades aos ministros, separa claramente estes do poder real e inviolável"57.

Entre nós, Dom Pedro I, ao outorgar a Constituição do Brasil de 1824, fê-la monárquica representativa, atribuindo ao Monarca o Poder moderador. expressamente consagrada no art. 98, da Constituição do Império do Brasil. Segundo este dispositivo, "o Poder Moderador é a chave de toda a organização politica, é delegado privativamente ao Imperador, como chefe Supremo da Nação, e o seu primeiro representante, para que vele sobre a manutenção da independência, equilíbrio e harmonia dos demais poderes politicos".
A definição do poder moderador foi

Com a proclamação da República no Brasil, desapareceu o parlamentarismo e, com ele, o poder moderador em nossa organização política. A definição contida no art. 98, da Constituição do Império, no entanto, preserva até os nossos dias um sentido de verdade.

$\mathrm{Na}$ Inglaterra e noutras democracias coroadas, o poder real continuou até os nossos dias a exercer a sua função de manutenção da unidade da nação, na condição de um poder moderador puro. Sobre as demais funções estatais, das quais fora gradativamente despido após o absolutismo, a Chefia de Estado passou a exercer um poder de fiscalização.

Para José Zafra Valverde, “... a função de chefia do Estado nos dá uma idéia, ou pelo menos tende-se a tê-la, de ser uma figura política central e superior às demais que compõem o Estado..." "18. "Este poder superior..." prossegue o autor "...de Chefia de Estado a Chefia, deve denominar-se "Poder de Autoridade" $" 59$.

Conclui o constitucionalista espanhol afirmando que "... apesar de suas pequenas possibilidades de influência a nivel de regras constitucionais, o chefe de Estado exerce sua autoridade com base em sua dignidade e personalidade integras, e sempre reconhecidas por todos",60.

Como característica própria deste Poder moderador, centralizador e unificador

56. TÔRRES, João Camillo de Oliveira, A Democracia Coroada - Teoria Política do Império do Brasil, pág 119.

57. REBECQUE, Henri Benjamin Constant de, Princípios Políticos Constitucionais: princípios políticos aplicáveis a todos os governos representativos e particularmente à Constituição atual da França (1814), pág. 73.

58. VALVERDE, José Zafra, Poder y Poderes, pág. 155.

59. VALVERDE, José Zafra, Poder y Poderes, pág. 155.

60. VALVERDE, José Zafra, Poder y Poderes, pág. 155. 
dos demais poderes e da própria nação, podemos apontar como a mais fundamental de todas a como sendo o exercício apartidário da função, que visa a atender os objetivos do Estado global ${ }^{61}$. O exercício da Chefia de Estado se da em nome do Estado como um todo e não fracionadamente ${ }^{62}$.

Dentre as principais atribuições do Chefe de Estado, contidas na Constituição Federal de 1988, podemos apontar a con vocação do Conselho de Defesa Nacional, a nomeação dos Ministros do Supremo Tribunal Federal e demais Tribunais Superiores, a representação do Brasil nas relações internacionais, a decretação do estado de defesa e do estado de sítio, o exercício do comando das Forças Armadas, etc...

\section{Função de Chefia de governo}

A função de chefia de governo assume um papel de extrema relevância na medida em que atua ativamente, dirigindo a política partidária e elaborando as leis conjuntamente com o poder deliberativo. É efetivamente, o poder que está mais capa citado para decidir acerca do desenvolvimento da coletividade ${ }^{63}$.

Atualmente, a chefia de governo propõe emendas constitucionais, projetos de leis, decretos legislativos, etc., de forma a dar impulso à dinâmica estatal. A contrari- edade aos objetivos do governo é o que se denomina de oposição $0^{64}$.

A oposição, neste sentido, tem fundamental importância ao apontar as falhas do governo. Este jogo entre oposição e governo constitui a base das sociedades pluralistas, pois, ela exerce a última instância de limitação do poder: o jogo do controle democrático.

Diferentemente da Chefia do Estado, a Chefia de Governo caracteriza-se pelo partidarismo, que se traduz na linha de ação político-ideológica da maioria. Esta linha de ação, nos Estados democráticos, são formuladas e submetidas à aprovação da opinião pública através dos partidos políticos ${ }^{65}$. Cabe a Chefia do Governo a função de exercício da direção político-administrativa do Estado ${ }^{66}$.

Para possibilitar o exercício desta fun ção, o Chefe de governo tem o poder de nomear os Ministros de Estado, de iniciativa de projetos de lei sobre diversas matérias, da edição de medidas provisórias, etc...

\section{Função Deliberativa}

As expressões corpo deliberativo, de Aristóteles, e Poder Legislativo, para Montesquieu, são sinônimas ${ }^{67}$.

O Parlamento, no entanto, não é um órgão que elabore com as leis com exclusi-

61. SOUZA JUNIOR, Cesar Saldanha, A Crise da Democracia no Brasil, pág. 82.

62. SOUZA JUNIOR, Cesar Saldanha, A Crise da Democracia no Brasil, pág. 82

63. VALVERDE, José Zafra, Poder y Poderes, pág. 153.

64. SOUZA JUNIOR, Cesar Saldanha, A Crise da Democracia no Brasil.

65. SOUZA JUNIOR, Cesar Saldanha, A Crise da Democracia no Brasil, pág. 85

66. VALVERDE, José Zafra, Poder y Poderes, pág. 153

67. ARISTÓTELES, A Política, pág. 202.

Revista da Faculdade de Direito da UFRGS, v. 13, 1997

vidade. A elaboração das leis é o resultado de um trabalho coordenado entre a Chefia de Governo e o Parlamento. Sendo que, a estratégia político partidária é de iniciativa da Chefia de Governo.

Assim, a elaboração de leis, ou melhor, a função legislativa, nada mais é do que o fruto da atuação destes dois órgãos.A Chefia de Governo exerce a função de direção política, cabendo ao Parlamento, por sua vez, a função de aprovação dos projetos e controle da atuação governamental. Em linguagem popular, todavia, a palavra governo designa apenas a Chefia de Governo, exluíndo a atuação do Parlamento.

Nos Estados constitucionais, tanto os órgãos que exercem a função deliberativa quanto a função de direção política, se constituem de cidadãos-representantes eleitos por sufrágio.

A função deliberativa ou do Poder legislativo, tem evoluído, mesmo nos sistemas presidencialistas, como um órgão mais de contribuição para as tomadas de decisão do governo, do que pelo seu caráter de órgão legislativo puro e exclusivo, idealizado originariamente $^{68}$

Modernamente, o Parlamento apresenta três características básicas: de repre-

68. VALVERDE, José Zafra, Poder y Poderes, pág. 162.

69. SCHMITT, Carl, Die geisteschichtiliche lage des heutingen Parlamentarismus, págs. 41 a 43, apud, VALVERDE, José Zafra, Poder y Poderes, pág. 162.

70. SCHMITT, Carl, Die geisteschichtliche lage des heutingen Parlamentarismus, págs. 41 a 43, apud, VALVERDE, José Zafra, Poder y Poderes, pág. 162.

71. SCHMITT, Carl, Die geisteschichtiche lage des heutingen Parlamentarismus, págs, 41 a 43, apud, VALVERDE, José Zafra, Poder y Poderes, pág. 162

72. BOBBIO, Norberto, O Futuro da Democracia - Uma defesa das regras do jogo, pág. 68.

73. BOBBIO, Norberto, O Futuro da Democracia - Uma defesa das regras do jogo, pág. 68. sentação, de discussão e de publicidade ${ }^{69}$.

A representação parlamentar através conquista do direito de sufrágio univer democracias modernas ${ }^{70}$. O parlamento de hoje reúne ideologias as mais diversas, garantindo o direito de participação de várias facções políticas, que se dividem enque sustenta o governo, e a a fiscaliza o governo: processo democrático de controle e limitação do po-

A discussão parlamentar e a troca de idéias sobre as decisões políticas procuram traduzir a vontade geral da sociedade. Dentro da concepção rousseauniana de contrato, têm a virtude de obrigar os governantes a buscar uma vontade comum para se chegar ao consenso ${ }^{71}$.

O Parlamento é o termômetro da democracia, onde suas regras fundamentais, são amplamente aplicadas ${ }^{72}$. A sua legitimidade depende do consenso verificado is que o parlamento aprova dependem da decisão da maioria dos parlamentares ${ }^{73}$

Fundamentalmente, aplica-se nestes dois níveis de votação - do povo elegendo

Revista da Faculdade de Direito da UFRGS, v. 13, 1997 sal, sem dúvida nenhuma constitui a base 
seus representantes e do parlamento aprovando leis - o princípio máximo da democracia: o princípio da maioria.

O Parlamento é a base de sustentação político-partidária da Chefia de Governo. Sem o apoio do Parlamento o Governo não consegue exercitar seu plano político dependente de legislação nova. $\mathrm{O}$ artigo 48 da nossa Constituicão Federal, consagra a regra geral, atribuindo "... ao Congresso Nacional, com a sanção do Presidente da República, (...), a competência para dispor sobre todas as matérias de competência da União".

Por fim, não se deve esquecer que, todas as atividades do Parlamento são públicas e devem ser públicas para atingir o ideal democrático ${ }^{74}$. Isto para que cada cidadão possa tomar conhecimento e fazer o juízo crítico acerca do desempenho de seus representantes, o que possibilita um amadurecimento político da sociedade e o aperfeiçoamento da democracia. Neste sentido papel muito importante desempenham os meios de comunicação do país, razão pela qual a liberdade de opinião de cada indivíduo e mesmo dos meios de comunicação são fundamentais no jogo democrático ${ }^{75}$.

\section{Função Administrativa ou Executiva}

A Administração Pública deve ser entendida como o órgão que executa as decisões políticas tomadas pelo Governo ${ }^{76}$.

Esta função corresponde ao que a doutrina tradicional denomina por Função Executiva. Nesta acepção, deve-se entender que a Função Administrativa se aplica tanto às decisões políticas como aquelas disposições de caráter técnico-utilitário, necessárias a vida em comunidade ${ }^{77}$.

Num sentido dinâmico, Giorgio Pastori, afirma que Administração Pública é o órgão que realiza o conjunto das atividades diretamente destinadas à execução concreta das tarefas ou incumbências, consideradas de interesse público ${ }^{78}$.

No mesmo sentido, Charles Debbasch: "Administração Pública é o conjunto de meios institucionais, materiais, financeiros e humanos preordenado à execução das decisões políticas"79.

Pode-se dizer que a atividade administrativa é subordinada ao poder de direção política, na medida em que seus órgãos são comandados por Ministros nomeados pelo Chefe de Governo. Basicamente, a fun-

74. SCHMITT, Carl, Die geisteschichtliche lage des heutingen Parlamentarismus, págs. 41 a 43, apud, VALVERDE, José Zafra, Poder y Poderes, pág. 162

75. SCHMITT, Carl, Die geisteschichtliche lage des heutingen Parlamentarismus, págs. 41 a 43, apud, VALVERDE, José Zafra, Poder y Poderes, pág. 162

76. LOEWENSTEIN, Karl, Teoria de la Constituicion, pág. 66

77. LOEWENSTEIN, Karl, Teoria de la Constituicion, pág. 66.

78. PASTORI, Giorgio, Dicionário de Politica, pág. 12.

79. DEBBASCH, Charles, Institutions Administratives, pp. 10-12, apud, SILVA, José Afonso da, Curso de Direito Constitucional Positivo, pág. 551.

Revista da Faculdade de Direito da UFRGS, v. 13, 1997 ção administrativa tem por finalidade a execução da política governamental vigente.

Para atingir seus objetivos a Função Administrativa se utiliza de um aparato de burocratas, composto de um corpo de funcionários necessários à consecução de seus fins, de empresas públicas, autarquias, fundações e sociedades de economia mista. Tais circunstâncias alçam o Poder executivo à condição de ser emtermos orgânicos o maior de todos os poderes.

O extremo crescimento da máquina administrativa, através das empresas estatais, fundações e autarquias públicas, tem sido uma marca dos Estados contemporâneos intervenionistas do século $\mathrm{XX}^{80}$. Neste final de século, no entanto, já fala-se da crise do Estado intervencionista, incapaz de gerenciar eficientemente os seus emprendimentos.

\section{Função Jurisdicional}

A Função Jurisdicional, desde Aristóteles, passando por Montesquieu, até os nossos dias, ainda guarda o conteúdo significativo original. Não sem razão, pois que suas características são bem definidas.

A Função Judiciária consiste, basicamente, no sistema pelo qual a sociedade delega a um terceiro, sujeito imparcial, a incumbência de compor os litígios entre os indivíduos. A composição dos litígios deve ser obtida com base na vontade geral de uma sociedade, expressa nas leis. Este é o princípio ortodoxo, que deve ser visto com flexibilidade.

80. LOEWENSTEIN, Karl, Teoria de la Constituicion, pág. 66.

81. BOBBIO, Norberto, Estado, governo, sociedade; por uma teoria geral da política, pág. 83.
Não é objeto do presente trabalho a discussão acerca do problema da prestação jurisdicional adstrita à lei, ou não. Mas é inegável o fato de que ao Poder Judiciário incumbe, de regra, o dever de interpretar e aplicar a lei geral e abstrata ao caso, que é concreto e específico.

Como características, podemos dizer que a Função Jurisdicional, deve ser apartidária. Nenhuma das pessoas que exercem esta função deve ter a chamada responsabilidade político-partidária.

A responsabilidade político-partidária, está vinculada a um determinado partido político (que pode ser majoritário ou não).

A atividade jurisdicional, diversamente, é exercida em prol da totalidade. Esta característica, impõe ao magistrado o dever de julgar a favor do direito objetivo vigente, muitas vezes em detrimento das motivações ideológicas subjetivas.

Isto implica na obrigação daqueles que exercem a Função Jurisdicional, de compor os litígios existentes em favor do todo, conciliando as relações existentes entre fortes e fracos - sociedade e Estado mantidas com base no poder político; entre ricos e pobres, mantidas com base no poder econômico; e entre sábios e ignorantes, mantidas com base no poder ideológico ${ }^{81}$.

Nas sociedades pluralistas esta missão compreende, genericamente falando, compor litígios entre superiores e inferiores.

Revista da Faculdade de Direito da UFRGS, v. 13, 1997 
As regras de composição destes litígios são expressas nas leis, para as quais todas estas forças colaboram para sua elaboração. A soma destas relações de poder compõe a totalidade das pessoas políticas do Estado. E estas, nos Estados constitucionais, firmam o pacto de se submeter às decisões da maioria, regra fundamental do processo democrático de auto regulamentação da sociedade. Nesce pacto se inclui, evidentemente, o Poder Judiciário, o qual deve se submeter às regras do jogo democrático. A ele o inciso XXXV, do artigo $5^{\circ}$, da Constituição Federal, outorga ao Poder Judiciário o monopólio da jurisdição.

\section{Considerações finais}

Com base nos fatos históricos e da análise dos autores citados, podemos concluir que há, em linhas gerais, uma nítida distinção entre as funções estatais exercidas pelo Estado, de forma a podermos dividi-la em dois grupos:

De um lado, temos aquelas funções que devem ser exercidas em nome da sociedade global e que se caracterizam pela pretensão de serem totalitárias ou absolutas na consecução dos seus fins. Estas, mesmo atingindo sua plenitude, não estarão suprimindo a sociedade pluralista, ao contrário, tenderão a torná-la mais justa. Tais funções são aquelas que se caracterizam por serem apartidárias, pois visam antes de tudo atingir os objetivos do Estado como um todo ${ }^{82}$. A justiça social utópica seria atingida na sociedade pluralista, ainda que em horizon- tes distantes, se todas as funções pudessem ser exercidas na sua totalidade, em busca dos fins da unidade dentro das diversidades. Podemos classificar com estas características as funções de Chefia de Estado, Administrativa e Jurisdicional.

De outro lado, temos aquelas funções que não podem ser exercidas de forma totalitária, na medida em que as pessoas não têm um ideal político unitário e absoluto. São aquelas funções que visam os objetivos de governo e que se baseiam no princípio democrático da maioria; que buscam o consenso, permitindo o dissenso ${ }^{83}$.

Estas funções são, em razão disto, partidárias tendo como corredores de ligapolíticos. São as funções, de Chefia de Governo e de Deliberação, que tomam as decisões políticas fundamentais de um Estado a que Rousseau, Locke e Montesquieu substancialmente designariam de Poder Legislativo.

\section{B) Separação de Funções}

\section{Considerações iniciais}

O princípio da separação das funções estatais surgiu como forma de combater o absolutismo, através do enfraquecimento das possibilidades do exercício tirânico do Poder. Se a união faz a força, a sua desunião, contrario sensu, enfraquece o poder.

Aristóteles, analisando as constituições das cidades-estado gregas, identificou as funções de deliberação, execução e jução entre o povo e o governo, os partidos

82. SOUZA JUNIOR, Cesar Saldanha, A Crise da Democracia no Brasil, pág. 82.

83. SOUZA JUNIOR, Cesar Saldanha, A Crise da Democracia no Brasil, pág. 84.

Revista da Faculdade de Direito da UFRGS, v. 13, 1997 risdição ${ }^{84}$. Todavia, como observa Loewenstein, "... Aristóteles intentó un análisis de las funciones estatales según su substancia ...", o que não nos permite dizer que ele pretendia atribuir a órgãos diferentes cada uma destas funções objetivando a limitação do poder estatal ${ }^{85}$.

A noção de separação de poderes, como forma de limitação do abuso de poder, teve como ponto de partida a história inglesa, onde o parlamento conseguiu pela força impor-se às Monarquias absolutas até então existentes.

O marco desta luta foi a revolução gloriosa, com a derrubada do Rei Jaime II.

John Locke, foi o grande defensor da autoridade do parlamento inglês frente ao Rei, após a revolução gloriosa.

Para Locke, os poderes legislativo e executivo deveriam ser separados, ao justificar que "...pode ser tentação demasiado grande para a fraqueza humana, capaz de tomar conta do poder, que as mesmas pessoas que tem por missão elaborar as leis também tenham nas mãos a missão de pô-las em prática, ficando desta maneira isentas de obediência às leis que fazem, e podendo amoldar a lei, não só quando a elaboram como quando a põem em prática, a favor delas mesmas, e assim passarem a ter interesses distintos do resto da comunidade contrário ao fim da sociedade e do governo" $"$.

Foi, no entanto, do aristocrata Montesquieu, o mérito de ter elaborado a

84. ARISTÓTELES, A Política, livro VI, capítulos XI, XII e XIII.

85. LOEWENSTEIN, Karl, Teoria de la Constituicion, pág. 57.

86. Locke, John, Segundo Tratado Sobre o Governo, pág. 97.

87. MONTESQUIEU, Do Espírito das Leis, pág. 80.

88. MONTESQUIEU, Do Espírito das Leis, pág. 80 teoria da separação de poderes, com a instituição de um terceiro poder independente: o poder judiciário.

O princípio da tripartição de poderes, concebido por Montesquieu, foi resultado do estudo da república romana e da realidade inglesa. Montesquieu estudou na Inglaterra onde leu as obras de Locke e tomou conhecimento de suas idéias.

Pregou a tripartição de poderes, atribuindo a cada órgão o exercício de uma função. Tinha em mente combater os regimes absolutistas, concentrados e ilimitados, através de um sistema de divisão do exercício do poder político em órgãos distintos.

Segundo Montesquieu "quando na mesma pessoa ou no mesmo corpo de magistratura o poder legislativo está reunido ao poder executivo, não existe liberdade, pois pode-se temer que o mesmo monarca ou o mesmo senado apenas estabeleçam leis tirânicas para executá-las tiranicamente" 87 .

Ao sustentar a independência do judiciário, afirma que "não haverá também liberdade se o poder de julgar não estiver separado do poder legislativo e do executivo. Se estiver ligado ao poder legislativo, o poder sobre a vida e a liberdade dos cidadãos seria arbitrário, pois o juiz seria legislador. Se estivesse ligado ao executivo, o juiz poderia ter a força de um opressor"88.

A separação tinha por objetivo a garantia da liberdade dos cidadãos. A Declara- 
ção de Direitos de 1789 estabeleceu o princípio da separação de poderes como caracterizador do Estado constitucional liberal, o qual, ainda sobrevive atualmente como técnica destinada a garantir as liberdades individuais ou privadas.

As antigas distinções das formas de Governo de Aristóteles entre monarquia, aristocracia e democracia ${ }^{89}$, ou mais recentemente, a partir da época moderna, a distinção de Maquiavel entre monarquia e república, não tem mais predominado na doutrina política ${ }^{90}$.

Karl Loewenstein apresenta-nos uma classificação contemporânea, que superou as antigas distinções de forma de governo nos Estados constitucionais modernos ${ }^{91}$.

Utiliza como base desta classificação a dicotomia separação-concentração de funções para designar os Estados constitucionais e autocráticos, respectivamente baseado na doutrina de separação de poderes de Montesquieu ${ }^{92}$

Os Estados autocráticos ou totalitários, observa Loewenstein, caracterizam-se pela atividade de um só órgão político con-

89. ARISTÓTELLES, A Política, livro VI. N. do autor: A monarquia, para Aristóteles, é o governo do Estado exercido por uma só pessoa. Nas cidades-estado, como vimos na parte histórica, as monarquias se fundavam no culto aos antepassados; a sua degeneraçăo caracterizava o governo tirânico. 0 governo aristocrático era 0 exercido pelos chetes de familia em conjunto; também se baseava inicialmente no culto aos antepassados, na nobreza do sangue das pessoas que tinham religiáo; a degeneraçăo desta forma boa de governo era a chamada oligarquia. A democracia compreendida como o governo de todos também for descrita na parte histórica deste trabalho; a forma degenerada era a demagogia.

90. MAQUIAVEL, Nicolau, O Príncipe, pág. 13

91. LOEWENSTEIN, Karl, Teoria de la Consitituicion, pág. 50.

2. LOEWENSTEIN, Karl, Teoria de la Constituicion, pág. 50 .

93. LOEWENSTEIN, Karl, Teoria de la Constituicion, pág. 50.

94. LOEWENSTEIN, Karl, Teoria de la Constituicion, pág. 54.

95. LOEWENSTEIN, Karl, Teoria de la Constituicion, pág. 54

96. LOEWENSTEIN, Karl, Teoria de la Constituicion, pág. 51.

97. LOEWENSTEIN, Karl, Teoria de la Constituicion, pág. 51.

Revista da Faculdade de Direito da UFRGS, v. 13, 1997

centrar sob as suas mãos todas as funções estatais ${ }^{93}$. Normalmente, estes Estados são governados sob uma disciplina semelhante à dos exércitos, exemplifica ${ }^{94}$.

Já os Estados constitucionais caracterizam-se pela distribuição do poder em vários órgãos independentes e que somados formam a unidade do poder político ${ }^{95}$. As ditaduras latino-americanas predominantes nos anos 60 e 70, muito embora formalmente suas constituições organizassem o Estado com poderes independentes, eram Estados pseudo-constitucionais, pois os demais poderes ficavam submetidos ao ditador $^{96}$. O que importa nesta classificação é uma separação ou concentração de poderes substancial, baseada na realidade ${ }^{97}$.

O princípio da separação de poderes ou funções estatais ultrapassa a simples finalidade de organização e divisão do trabalho para o exercício do Poder Político, para caracterizar aqueles Estados onde a liberdade política, religiosa, de opinião, ideológica, econômica estão garantidas.

Em outras palavras, a separação de poderes garante o direito a cada cidadão de 
Ao Poder Judiciário cabe o controle da legalidade dos atos do Poder Executivo e da constitucionalidade das leis elaboradas entre este e o Poder Deliberativo (Congresso Nacional). A limitação da atuação do Poder Judiciário se dá na medida em que este deve aplicar o direito objetivo elaborado entre o Poder Executivo e o Poder Deliberativo.

Assim, o sistema tripartido de Montesquieu visa o exercício do Poder Político dividido entre três órgãos independentes entre si e que se encontram num mesmo plano hierárquico; nenhum destes órgãos sozinho possa exercer a atividade política sem a aquiescência do outro.

De modo geral, salvo se os membros dos três órgãos que compõe o Estado logra rem unidade de opinião e cooperarem de maneira harmoniosa, nenhuma das principais funções do Estado poderá ser devidamente exercida ${ }^{98}$.

Concluindo, se um ou dois dos poderes procurarem ir adiante de suas atribuições constitucionais, estarão limitados pelo terceiro, num sistema de freios e contrapesos.

Muito embora as Funções Estatais não correspondam exatamente àquelas idealizadas por Montesquieu, o fato é que o sistema de freios e contrapesos é eficiente, anulando o exercício despótico do Poder Político.

\section{Dinâmica do Sistema \\ Parlamentarista}

O sistema de governo parlamentarista surgiu como uma evolução histórica natu-

ral na Inglaterra, posterior à doutrina de Locke e Montesquieu. É adotado na quase totalidade dos Estados da europa ocidental, tanto na forma de repúblicas (Alemanha, França e Itália) quanto na forma de monarquias constitucionais (Inglaterra e Espanha).

O parlamentarismo distingue-se do presidencialismo, em termos orgânicos, pela separação das funções de Chefia de Estado e Chefia de Governo em órgãos distintos. O Presidente, nas Repúblicas, ou o Rei, nas Monarquias, passou a exercer a Chefia de Estado. A Chefia de Governo é exercida pelo Primeiro Ministro que é escolhido pelo Chefe de Estado dentre um dos parlamentares do partido majoritário do Parlamento. Normalmente é escolhido como Primeiro Ministro o líder do Partido Majoritário.

A doutrina moderna têm sustentado, a partir de Loewenstein, a independência orgânica da Função Administrativa, de forma que, neste sistema, cada uma das Funções seria de fato exercida por órgãos independentes.

A Função de Chefia de Estado deve ser desempenhada em favor da totalidade. Isto tem como conseqüência prática que o Chefe de Estado exerce sua função desvinculado dos compromissos políticopartidários, na medida em que não participa do processo legislativo. Atua apenas com sua autoridade moral dentre os demais poderes, com o fito de harmonizá-los.

De outra parte, a Função de Chefia de Governo, fica desvinculada e livre para

\section{LIPSON, Leslie, Os Grandes Problemas da Ciência Polifica, pág. 348.}

Revista da Faculdade de Direito da UFRGS, v. 13, 1997 atuar, imprimindo sua política partidária com o apoio do Poder Deliberativo, os quais necessariamente harmônicos, têm a missão de elaborar as leis.

Esta separação é conveniente porque os objetivos do Estado e do Governo são distintos. Enquanto a Chefia de Estado deve ser apartidária, representando a sociedade como um todo, a Chefia de Governo deve ser partidária para ter maior eficiência, imprimindo a política da maioria e não da totalidade.

O Estado, para se governar deve ter um rumo a seguir. Este rumo só pode ser vislumbrado através de decisões políticas que satisfaçam a uns em detrimento de outros, sob pena de se condená-lo a imobilidade. O critério mais justo numa sociedade que estabelece o princípio da igualdade política é colocar o Governo do Estado nas mãos da maioria. Este já era um dos postuilados de John Locke, para quem "...todo homem, concordando com outros em formar um corpo político, assume a obrigação para com todos os membros desta sociedade de submeter-se à resolução da maioria.."

Outro resultado importante desta divisão é a possibilidade de distinguir melhor os atos de oposição dos atos de subver são. A crítica aos objetivos do Governo sempre será vista como expressão de oposição da minoria, enquanto a crítica aos objetivos próprios do Estado, que representa

99. LOCKE, John, Segundo Tratado Sobre o Governo, pág. 77.

100. SOUZA JUNIOR, Cesar Saldanha, A Crise da Democracia no Brasil, pág. 83.

101. JENNINGS, Sir William Ivor, A constituição britânica, pág. 83.

102. VERDU, Pablo Lucas e LA CUEVA, Pablo Lucas Murillo de, Manual de Derecho Político, vol. I, pág. 187.

103. VERDU, Pablo Lucas e LA CUEVA, Pablo Lucas Murillo de, Manual de Derecho Político, vol. I, pág. 187.

Revista da Faculdade de Direito da UFRGS, v. 13, 1997 a todos, é uma crítica a si mesmo que caracteriza a subversão ${ }^{100}$

Como bem nos relata Sir Ivor Jennings, na Inglaterra pode-se amaldiçoar o governo e aclamar a rainha, o que significa em outras palavras a existência de uma oposição contra o governo, mas a favor do Estado ${ }^{101}$

No que se refere às relações entre Chefe de Governo e Poder Deliberativo, este sistema exige harmonia entre os dois poderes, na medida em que a direção política passa a ser exercida por um Governo proveniente do consenso formado com a maioria Parlamentar.

Esta homogeneidade entre os titulares de ambos os órgãos faz com que o princípio da separação de poderes perca seu sentido inicial de auto-anulação ${ }^{102}$.

Esta harmonia decorrente da sintonia política entre a Chefia de Governo e o Poder Deliberativo, de um lado, impede o exercício da função legislativa num só órgão, e, de outro, permite o funcionamento do Governo dentro do princípio democrático da maioria ${ }^{103}$

Neste sistema a limitação do Poder é exercida efetivamente pela maioria, verticalmente, pois o consenso entre a Chefia de Governo e o Poder Deliberativo é uma necessidade para a sustentação política dos indivíduos que compõe os dois órgãos. As. 
sim, enquanto houver respaldo da maioria, o Governo do Estado será hábil para impor a sua política, isto é, o seu plano de Governo.

O consenso é a base para manutenção dos dois órgãos político-partidários do Estado. Quando não houver consenso entre um e outro órgão, dissolve-se o parlamento e convocam-se novas eleições, para que o povo decida sobre conflito de orientações políticas.

Havendo um controle democrático eficiente, através da política partidária, forma-se um Estado dinâmico, em condições de agir e intervir na sociedade quando necessário.

Também, no sistema parlamentar moderno, a Função Administrativa é exercida separadamente da Chefia de Governo e da Chefia de Estado. O Poder Administrativo é independente na medida em que é ele próprio quem forma os seus quadros de funcionários. $\mathrm{O}$ modo de seleção é por concurso público. Assim sendo, nem os parlamentares, nem o Chefe de Governo e nem o Chefe de Estado podem interferir na sua composição. O Poder Executivo ou Administrativo, deve ser formado de funcionários profissionais.

Claro que a administração fica sob o comando político do governo, mas sua função deve ser exercida com objetivos apartidários.

\section{Considerações finais}

Em resumo, os dois sistemas de governo contemporâneos, que, na classifica- ção de Loewenstein caracterizam os Estados constitucionais, são regidos por princípios semelhantes, porém distintos entre $\mathrm{si}^{104}$.

Semelhantes na medida em que ambos adotam o sistemas de separação de poder como forma limitação da atuação do Estado.

O sistema presidencialista concebido em uma época em que o processo democrático ainda não era eficiente, baseia-se na igualdade e independência dos três poderes. Assim o fazendo, cumpre sua missão primordial de auto anulação do poder.

O sistema parlamentarista, têm como objetivo amenizar o conflito entre os órgãos de exercício do Poder, de um lado, com o chamado Poder Moderador na qualidade de mediador destes conflitos, e, de outro, da necessidade de atuação conjugada e harmônica entre os órgãos elaboradores da legislação.

\section{IV - Conclusão Geral}

Desde a formação das famílias, das tribos e das cidades-estado greco-romanas, passando para a sociedade feudal, e, finalmente, aos Estados nacionais modernos, fenômeno semelhante tem ocorrido, fruto da necessidade do ser humano se organizar em grupo: a divisão das sociedades entre governantes e governados.

Da divisão das sociedades entre governantes e governados, visto que ambos os pólos integram o mesmo grupo, decorre necessariamente uma relação de poder, ou seja, de mando-subordinação.

104. LOEWENSTEIN, Karl, Teoria de la Constituicion, pág. 50-51.

Esta relação de mando-subordinação tem se caracterizado pelo poder de coercitibilidade física dos governantes sobre os governados, a qual, nesta condição, se denomina por relação política fundamental.

As relações políticas têm sido dolorosas no transcorrer da história, e estando o governante na posição de mando, a luta do homem para conquistá-la tem sido uma constante.Os governantes, dispondo da coação física, cometeram as maiores atrocidades, variando a sua intensidade de governo a governo, o que por si só justifica o estudo das Funções do Estado e de sistemas de governo mais eficientes que evitem a continuidade destes fatos. Entenda-se por sistema a forma de organização dos órgãos de exercício de Funções Estatais.

Funções Estatais e sua organização são dois aspectos que analisamos na segunda parte do trabalho, sobre as quais apresentamos as seguintes conclusões.

Quanto aos órgãos que exercem as Funções Estatais, conquanto sejam exercidos por seres humanos, verifica-se a mesma necessidade de se os dividir entre os que devem mandar e os que devem ser mandados, nas relações que mantêm entre si. Disto resulta uma necessária hierarquia que vem a superar qualquer igualdade formal eventualmente determinada na Constituição.

A esta realidade não podemos fechar os olhos, e aquelas pessoas que represen- tam estes poderes, embora independentes, sob o ponto de vista formal e funcional, ao exercitar suas funções, devem ter consciência disto para melhor desempenhá-la.

Em resumo, As Funções do Estado, como já relatado, são a Chefia de Estado, que exerce a sua função baseado na sua autoridade; a Chefia de Governo, que exerce a direção da política; o Poder Deliberativo; o Poder Executivo; o Poder Judiciário ${ }^{105}$.

Com base nas características gerais que embasam o exercício das funções do Estado, e considerando que todas elas formam a unidade do Poder Político, podemos traçar uma escala hierárquica exitente no âmbito das relações que elas mantém entre si.

Chefe de Estado, situa-se acima dos outros órgãos de exercício de funções do Estado, exercendo, com base na sua autoridade imanente, a função moderadora das relações existentes entre os demais poderes.

Em posição intermédia, temos a Função de Chefia de Governo e de Deliberação. Ambas as funções, coordenamente, promovem a estratégia política do Estado de Direito, legitimados pelo voto, em cada a momento histórico.

A direção política cabe ao Chefe de Governo, a qual só pode ser exercida com o respaldo do Parlamento. As Leis são fruto da atuação coordenada de ambas as funções, as quais, num sentido amplo, exercem a função legislativa. 
Para John Locke, “... o poder legislativo é o que tem o direito de estabelecer como se deverá utilizar a força da comunidade no sentido da preservação dela própria e dos seus membros ${ }^{106 " . ~}$

Num plano inferior, situam-se as Funções Administativa e Jurisdicional Ambas as funções estatais, de Administração e de Jurisdição, guardam íntima conexão, na medida em que, basicamente, estão a cumprir as diretrizes políticas postas pelo Estado democrático.

A diferença essencial entre ambas, segundo Leslie Lipson, está no fato de que a primeira tem por finalidade fazer cumprir as leis, ao passo em que, a segunda, espera que surja um litígio e que uma das partes busque obter uma decisão judicial ${ }^{107}$.

Como se vê, ambas as funções, de administração e de jurisdição, aplicam as leis emanadas dos órgãos legiferantes. Num sentido amplo, pode-se dizer que ambas exercem funções executivas.

Voltando a relação superior-inferior existente entre as funçōes legislativa e exe cutiva, deve-se mencionar que a mesma já era sustentada Jean-Jacques Rousseau e John Locke. Segundo Rousseau “... não se poderia ter uma constituição melhor do que aquela em que o poder executivo estivesse jungido ao legislativo" 108 .

No mesmo sentido, Locke afirmava que "...enquanto subsiste o governo, o

106. LOCKE, John, Segundo Tratado Sobre o Governo, pág. 97. 107. LIPSON, Leslie, Os Grandes Problemas da Ciência Política, pág. 349 108. ROUSSEAU, Jean-Jacques, Do Contrato Social, pág. 89. 109. LOCKE, John, Segundo Tratado Sobre o Governo, pág. 97. legislativo é o poder supremo; o que deve dar as leis a outrem deve ser-lhe necessariamente superior..."109.

Esta situação de subordinação da administração e da jurisdição às diretrizes postas na legislação, não quer dizer que no desempenho de suas atribuições não se possam recorrer a fontes jurídicas praeter legem. Como sabemos, a ordem jurídica é lacunosa. Muitas vezes, depara-se o Juiz com casos concretos novos, não regulados sequer por analogia legal ou jurisprudencial. Nestas ocasiões solução exige a criação jurisprudencial do Direito. Semelhantes aporias ocorrem também na Administração Pública

Por isto não se pode resumir as ativi dades administrativa e jurisdicional a mera execução de leis. Todos sabemos que tratam-se de atividades interpretativo-executivas, muitas vezes, criando nova norma para o caso concreto.

Esta realidade, todavia, não altera a superioridade daqueles que tempor atividade fim a criação de leis, sobre aqueles que tem por atividade fim a execução de Leis.

Claro que cabe ao judiciário realizar o controle da legalidade dos atos legislativos interpretando e executando a norma constitucional. Todavia, a inconstitucionalidade de leis não é a regra dos atos legislativos. Ao contrário, sendo as leis de regra constitucionais, têm-se na mesma medida, e como regra, a submissão do judiciário às leis do poder legislativo.

Por isto, o judiciário, como poder submisso à ordem vigente emanada principalmente através do Poder Legislativo, deve interpretar as normas em favor das regras postas pelo Estado democrático.

O presente trabalho expõe as principais opções de organização do exercício das funções estatais, quais sejam, o sistema presidencialista e o sistema parlamentarista.

Nos países que adotam qualquer destes sistemas, constata-se a realidade da existência do exercício limitado do poder político, tal como preconizado John Locke e Montesquieu. Estes vislumbraram na separação de poderes, até então concentradas nas mãos de monarcas absolutistas, o grande instrumento de tutela do cidadão contra a violação dos seus direitos fundamentais.

Neste século XX, a separação de poderes continua a ser um instrumento eficaz na defesa dos direitos humanos. É com base neste critério que Karl Loewenstein, na esteira dos clássicos, classifica os Estados como totalitários ou constitucionais ${ }^{110}$. No primeiro caso, não há separação de poderes; no segundo caso, a separação de poderes se organiza nos sistemas presidencialista ou parlamentarista de governo.

No sistema tripartido de Montesquieu, pode-se dizer, que além de limitar o exercício do poder através da separação de funções, este visa, com o sistema de freios e contrapesos, a sua auto-anulação. Soma-se a estes dois, o limite do controle democrático sobre o Poder Legislativo.

A auto-anulação do poder, neste caso, ocorre em todas as ocasiões em que o Chefe de Governo não obtém o apoio da maioria parlamentar.

O mesmo fenômeno decorre também da união das funções de Chefia de Estado, de Chefia de Governo e da Administração Pública, incompatíveis entre si, num só órgão estatal: no Poder Executivo. E isto está ocorrendo na atual política brasileira.

O sistema parlamentarista, diferentemente, não visa a auto-anulação entre os poderes que exercem as Funções Estatais.

Neste sistema, distribui-se para cada órgão uma Função Estatal específica, para que a contradição de princípios entre as cinco funções, não imobilize o Estado na consecução de seus fins.

Do ponto de vista dinâmico, as relações entre os diversos órgãos, como decorrência desta separação, se faz efetivamente harmônica.

Acima de todos, o Chefe de Estado, independente e atuante na sua missão de moderador dos demais órgãos.

As relações entre os órgãos de Chefia de Governo e Poder Deliberativo, são

110. Nota do autor: Não tratamos no presente trabalho, da limitação vertical do poder estatal representada especialmente pela repartição territorial do poder nos Estados federados. Entendemos que tal abordagem não atenderia os objetivos do trabalho de análise de funçōes estatais. A limitaçăo horizontal, ou separação de poderes, ao contrário, nos parece fundamental ao exame das funçōes. $O$ exame da doutrina em geral é o grande testemunho desta realidade. 
sintonizadas através da necessária maioria parlamentar que sustenta o governo. Como decorrência disto, têm-se um governo atuante e intervencionista, na medida das aspirações e necessidades populares.

Mais abaixo, sob a direção dos demais, a Administração Pública e o Poder Judiciário. No que se refere a este último, há uma tendência nos sistemas parlamentares de se instituir o controle concentrado de constitucionalidade das leis, através de Tribunais Constitucionais, o que confere maior estabilidade e segurança à legislação.

A limitação da atuação do Estado, decorre primeiramente, tal como no presidencialismo, da separação de poderes. E, igualmente, tal como no presidencialismo, do controle democrático. Todavia, aqui, não ocorre o fenômeno da auto-anulação decorrente do desentendimento entre os poderes.

Em linhas gerais, estão expostos os dois principais sistemas de governo dos Estados constitucionais. Em 1993, foi realizado no Brasil um plebiscito através do voto direto, para escolha entre os sistemas presidencialista e parlamentarista. $O$ resultado, como sabemos, foi no sentido da manutenção dos sistema presidencialista vigente.

O funcionamento deste sistema presidencialista no Brasil, porque inadequado, tem sido desvirtuado, adquirindo algumas características próprias do parlamentarimo, v.g., em decorrência da expressiva edição de Medidas Provisórias,

que se tem constituído no maior instrumento de implementação das medidas governamentais.

Em nosso entender, utilizando-se das lições de Leslie Lipson, ao se eleger um sistema de governo, "... deve-se ter em vista que a estrutura estatal tem de variar na conformidade das necessidades de seus "consumidores", ou segundo os planos de seus "engenheiros", adequando-a à sociedade a qual os representantes do Estado pretendem dirigir"111.

Parece-nos que que a organização do sistema de governo no Brasil, que denota estar funcionando com características, nitidamente parlamentaristas, num sistema presidencialista, seria mais eficiente se se modernizasse, adotando de vez, a exemplo dos países da europa ocidental, o sistema parlamentarista.

\section{V - Bibliografia}

ARISTÓTELES, A Política, Hemus-livraria editora Itda., São Paulo, 1966.

BLOCH, Leon, Luchas Sociales en la Antigua Roma, Editorial Claridad, Buenos Aires, 1934.

BOBBIO, Norberto, O Futuro da Democracia - Uma defesa das regras do jogo, tradução de Marco Aurélio Nogueira, Editora Paz e Terra S.A., 4⿳亠丷a edição, São Paulo, 1989,

Estado, governo, sociedade; por uma teoria geral da política, tradução de Marco Aurélio Nogueira, Rio de Janeiro, editora Paz e Terra, 3ㄹ edição, 1990.

111. LIPSON, Leslie, Os Grandes Problemas da Ciência Política, pág. 332.

- As Ideologias e o Poder em Crise: pluralismo, democracia, soialismo, comunismo, terceira via e terceira força, tradução de João Ferreira, revisão técnica de Gilson Cesar Cardoso, 1 a reimpressão, Editora Universidade de Brasília, São Paulo, 1990.

BURNS, Edward Mcnall, História da Civilização Ocidental, Editora Globo S.A., Porto Alegre, 1957.

CAETANO, Marcelo, Direito Constitucional, vol. I, Companhia Editora Forense, 1 ${ }^{\mathrm{a}}$ edição, Rio de Janeiro, 1977.

CHEVALLIER, Jean-Jacques, As Grandes Obras Políticas: de Maquiavel a nossos dias, Livraria Agir Editora, 4⿳a edição, Rio de Janeiro, 1989.

CROISET, A., As Democracias Antigas, Livraria Garnier, Rio de Janeiro, 1923.

CRUMP, C. G., e JACOB, E. F, El legado de la Edad Média, ediciones Pegaso, traducido por J, Jesus Navarro de Palencia y Francisco Javier Osset, Madrid, 1950, pág. 606.

DE REBECQUE, Henri Benjamin Constant, Princípios Políticos Constitucionais: princípios políticos aplicáveis a todos os governos representativos e particularmente à Constituição atual da França (1814); organização e prefácio por Aurélio Wander Bastos; tradução de Maria do Céu Carvalho, editora Liber Juris Ltda., Rio de Janeiro.

DE COULANGES, Fustel, A cidade antiga, Livraria Martins Fontes Esitora Ltda, 2ª edição, São Paulo, 1987.
FERREIRA FILHO, Manoel Gonçalves, Curso de Direito Constitucional, editora Saraiva, 18 a edição, São Paulo, 1990, pág. 115.

GILISSEN, John, Introdução Histórica ao Direito, Fundação Calouste Gulbenkian, Lisboa, 1986.

HOBBES, Thomas, LEVIATÃ ou matéria, forma e poder de um Estado Eclesiástico e Civil, editora Abril S.A. Cultural e Industrial, coleção Os Pensadores, 1ª edição, 1974.

JENNINGS, Sir William Ivor, A constituição britânica, tradução de Carlos Alberto Lamback, Brasília, Editora Universidade de Brasília, 1981, pág. 83.

LEBRUN, Gerard, O que é poder, editora brasiliense, $2^{\text {a }}$ edição, São Paulo, 1981.

LIPSON, Leslie, Os Grandes Problemas da Ciência Política, Zahar Editores, $2^{\text {a }}$ edição, Rio de Janeiro, 1976, tradução de Thomaz Newlands Neto.

LOCKE, John, Segundo Tratado Sobre o Governo, editora Abril S.A. Cultural e Industrial, coleção Os Pensadores, 1 a edição.

LOEWENSTEIN, Karl, Teoria de la Constituicion, ediciones Ariel, Barcelona, 1970.

MAQUIAVEL, Nicolau, O Príncipe, editora Abril S.A. Cultural e Industrial, coleção Os Pensadores, $1^{\mathbf{a}}$ edição, 1973, tradução de Lívio Xavier.

MEIRELLES, Hely Lopes, Direito Administrativo Brasileiro, Editora Revista dos Tribunais, 14ª edição, pág. 24. 
MONTESQUIEU, Do Espírito das Leis, editora Abril S.A. Cultural e Industrial, coleção Os Pensadores, $1^{\text {a }}$ edição, 1973.

MOSCA, Gaetano, História das Doutrinas Políticas, completada por Gaston Bouthoul, Zahar Editôres, Rio de Janeiro, 1958.

PASTORI, Giorgio, Dicionário de Política, Editora Universidade de Brasília.

RADBRUCH, Gustav, Filosofia do Direito, Armado Armênio editor, $6^{\mathbf{a}}$ edição, Coimbra, tradução do Professro L. Cabral de Moncada.

ROPS, Daniel, História da Igreja de Cristo, II vol., Livraria Tavares Martins, Porto, 1960, traduzido por Eduardo Pinheiro.

ROUSSEAU, Jean-Jacques, Do Contrato Social, editora Abril S.A. Cultu- ral e Industrial, coleção Os Pensadores, $1^{\text {ạ }}$ edição.

SOUZA JUNIOR, Cesar Saldanha, A Crise da Democracia no Brasil, editora Forense, 1978, 1르 edição, Rio de Janeiro.

TOCQUEVILLE, Alexis de, A Democracia na América, Editora Itatiaia Ltda., Belo Horizonte, 1962, traduzido por Neil R. da Silva.

TÔRRES, João Camillo de Oliveira, A Democracia Coroada - Teoria Política do Império do Brasil, editôra Vozes Limitada, 2ª edição revisada, Petrópolis, RJ, 1964.

VALVERDE, José Zafra, Poder y Poderes, editora EUNSA, Pamplona, 1975.

VERDU, Pablo Lucas e LA CUEVA, Pablo Lucas Murillo de, Manual de Derecho Político, vol. I, editorial Tecnos, S.A., Madrid, 1987.

\title{
A Experiência de Harmonização das Legislações na Europa - Harmonização Autônoma? ${ }^{(*)}$
}

\author{
Nichael भR. Will \\ Professor da Universidade de Genebra - Suíça
}

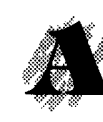

honra de falar perante à Comișão Austríaca de Direito Europeu, Direito Estrangeiro e Direito Internacional Privado inspirou-me na escolha do tema: a harmonização autônoma das legislações ${ }^{(* *)}$.

1. Há exatamente um ano atrás, o colega austríaco Ernst Kramer, que leciona na Suíça - o que não é nada extraordinário para um cidadão europeu - proferia uma palestra no Europa-Institut da Universidade do Sarre sobre o tema "A unificação do Direito Privado Europeu: instituições, métodos e perspectivas" ${ }^{1}$. Sua exposição centrava-se na complexa uniformização do Direito Privado na Europa Ocidental, nos moldes desenvolvidos pelas instituições internacionais. Ao lado da uniformização jurídica (Rechtsvereinheitlichung), referiu-se o colega ao fenômeno da "harmonização jurídica espontânea" ("spontane Rechtsangleichung"), citando exemplos no campo do direito matrimonial e de filiação e da proteção do consumidor: "nesta onda de reformas espontâneas em toda a Europa verifica-se, sob o manto das legislações nacionais e quase que na clandestinidade, $o$ nascimento de uma unidade jurídica européia". Conseqüentemente excluem-se as "recepções unilaterais (einseitige Rezeptionen) de direito estrangeiro, freqüentes no cenário europeu pela ação do legis-

Versão em Português do artigo publicado na obra "Österreichs Weg in die EG - Beiträge zur europäischen Rechtsentwicklung", F. Schwind (Hrsg.), OKW Verlag, Wien, 1991. Tradução e notas de Elaine Ramos da Silva, Tradutora de Alemão (UFRGS), Bacharel em Ciências Jurídicas e Sociais (UFRGS), LL.M. (Tübingen), revisão da Dra. Claudia Lima Marques, Professora Adjunto da Faculdade de Direito da Universidade Federal do Rio Grande do Sul. Este artigo de doutrina foi escrito antes da entrada da Áustria na Uniăo Européia (em 01-01-95) e aborda justamente a aproximação das legislaçóes, voluntária ou com vistas à integração econômica.

** Na oportunidade, agradeço a colaboração prestada pelo Senhor Assessor Hans-Ulrich Marticke.

1. Série "Vorträge, Reden und Berichte", Europa-Institut, n 139 , Saarbrücken, 1988. Ver também versão ampliada publicada no JBI. 1988, 477-489. 